\title{
Cross-Border Innovation in South-North Fair Trade Supply Chains: \\ The opportunities and problems of integrating fair trade governance into northern public procurement
}

\section{Abstract}

Fair trade is a means of governing South-North supply chains to increase the benefits of international trade integration for poor southern producers of agricultural and handicraft goods. Although the approach itself is arguably innovative in comparison with commercially orientated supply chains, many consider that its formalisation within third-party, Fairtrade International certification, has facilitated a process of conventionalisation. Furthermore, Fairtrade certification is considered to dominate producer and consumer attention; and therefore marginalise other more innovative and radical fair trade approaches, making differentiation increasingly difficult. The chapter investigates one aspect of this narrative by elucidating the effects of the Fairtrade Towns scheme: a promotional program viewed to be precipitating 'Fairtrade absolutism' within the wider movement. Focusing on the devolved region of Scotland, evidence for this process is uncovered and the implications for Southern producers highlighted through a parallel case study of the National Smallholder Farmers Association in Malawi. Here it is found that the costs of certification and their geographic restriction are actively isolating some producers; which combined with 'Fairtrade absolutism' in consumer countries undermines the principle of fairer access to northern export markets. The final section however, connects the producer and consumer cases, by reporting on an innovative fairly traded supply chain constructed between Malawian rice farmers and Scottish schools. Overall, the chapter highlights the continued potential for innovation within the fair trade movement, and suggests that such opportunities will emerge where supply chain actors are more proactively embedded in wider understandings of development and trade justice. 


\section{Introduction}

In general, fair trade is firstly concerned with building markets in more wealthy northern countries for poor southern producers of mostly artisan and commodity goods. Secondly, the broad approach requires that 'fair trade is a trading partnership, based on dialogue, transparency and respect, that seeks greater equity in international trade' (FINE 2001, p. 1). The current chapter however, examines the fair trade movement as a site of continual reflexive and dynamic innovation in the way that cross-border, south-north, supply chains are constructed and governed: particularly in the way that 'fair trade' itself is understood by those proclaiming to participate in this activity.

Fair trade practices emerged after World War Two when mission driven organisations sought to build south-north supply chains not for their own profit motivation, but to serve the welfare and development interests of marginalised southern producers. In this way, innovation emerged from the construction of supply chains that circumvented contemporary barriers to involvement in international trade networks and did so through genuine partnerships between private southern and northern stakeholders. In concrete terms this was achieved through the application of non-market forms of 'relational' governance (See: Gereffi et al. 2005): for example, in place of seeking to drive down prices paid to suppliers, northern buyers would aim to pay as much as possible after operational costs had been met (Brown 1993, pp. 164165; Littrell and Dickson 1999).

During this period, claims to fairness were based on trust relations and the social reputations of often religiously grounded actors such as Oxfam in the United Kingdom (UK) or the Mennonite International Development Agency in the United States of America (USA). However, this model was inherently limited for a number of reasons: not least by the fact that the 'alternative' nature of retailers, situating themselves within religious discourses, only appealed to a relatively small percentage of north consumers (LeClair 2002; Low and Davenport 2006, p. 319). In order to bypass this developmental blockage, southern and northern stakeholders again collaborated to innovate in the development of third-party certification for fair trade: initially under the name of Max Havelaar in Holland, but the principles and practices of which later informed the creation of an international network of 
labelling bodies operating under the central coordination of Fairtrade International (abbreviated to FLO, and represented by the specific legally trademarked term 'Fairtrade'12.

Although this institutionalisation of fair trade governance has facilitated tremendous growth of the movement, it is widely understood that this has been a double edged sword for two reasons: and it is argued here that the model of fair trade promoted by Fairtrade certification has been less innovative and more conventional than was initially envisioned. Firstly, the integration of fair trade goods into conventional supply chains has required the involvement of corporate actors in decision making processes concerned with the development of certification standards. As a consequence, it is suggested that the strength of initial principles and standards has been undermined: for example, in the opening up of Fairtrade certification to plantation style production, despite the initial mission of fair trade operation to support small farmers and artisans (see below). Secondly, although dedicated, mission driven and not-for-profit fair trade organisations have remained a strong part of the movement (either as part of Fairtrade certification networks or not), they have found it increasingly difficult to highlight the additional value they are perceived to provide. Therefore, it is argued, the success of the Fairtrade system is leading to the active marginalisation of other fair trade approaches and rendering it increasingly difficult for more innovative models to differentiate their activities from profit driven arrangements.

More specifically, this chapter critically investigates the effects of the Fairtrade Town scheme: an accreditation for place-based consumer communities first developed by Fairtrade International's UK member, the Fairtrade Foundation (Samuel and Emanuel 2012). Here existing analysis argues that the scheme has promoted the rise of 'Fairtrade absolutism' (Mohan 2010, p. 94) as Fairtrade certification has been prioritised over and above both other certification and alternative fair trade approaches. Having said this, the argument currently rests on the assumption that those communities seeking accreditation comply fully with the Fairtrade Foundation's specific requirements, despite the fact that non-compliance is common place within many private accreditation systems.

\footnotetext{
${ }^{1}$ Although the chapter uses the name Fairtrade International throughout the text, some documentary sources retain the name Fairtrade Labelling Organisations (FLO) as they originate from before the name change.

${ }^{2}$ This situation is more complex in reality given the break of Fair Trade USA from the wider international system, although this chapter does not consider this latest event in the history of fair trade.
} 
For this reason, research was designed to empirically investigate if the Fairtrade Town scheme is in fact conventionalising innovation within the fair trade movement. To present this work, firstly the case study of Scotland is discussed - chosen due to the devolved government's express support for fair trade - where it is identified that in many cases, the Fairtrade Towns scheme is indeed promoting the prioritisation of Fairtrade certified goods. The next section of the chapter provides an account of the consequences of this narrowing of fair trade innovation for producer communities, by presenting the perspective of the National Smallholder Farmers Association of Malawi (NASFAM): chosen as the largest association of smallholder farmers working within one of Scotland's major development partner countries. Here the problems of a 'hegemonic' (Herman 2010, p. 406) fair trade system are manifest as while NASFAM have had some success in exporting Fairtrade certified groundnuts, further efforts have been frustrated: to some extent by the cost of certification, but also by the geographic limitations imposed on other Fairtrade produce categories. Finally however, the third section of the chapter reports on what is argued to be the theme of continuing innovation preserved by the unique nature of more radical fair trade networks. Specifically, it is found that where organisations, including state institutions, are able to build relationships on the basis of critical understanding and trust, the problems and barriers of certification can be circumvented, and innovative pro-development supply chains still established.

\section{Fair Trade: A background of innovation and conventionalisation}

Fair trade activity as it is interpreted in this chapter emerged in the context of the international trade organisation and governance reform that followed the Second World War: two developments which taken together represented a significant effort at innovation in trade reform aimed at improving international inequalities. As Fridell (2007) identifies, the manipulation of market forces had long been used by the rich and powerful for the development of their own interests. However, 'what makes the [overall] fair trade movement unique is that it has aspired to use market regulation to protect the week, not the strong, and ideally to create a more equal international trade system' (Fridell 2007, p. 25). 
Although the use of non-market institutions by states and international organisations was ultimately frustrated by an emerging neoliberal agenda, a collection of more practical actions did survive. What emerged were grass roots, civil society based innovations that sprung up simultaneously, and collectively offered parallel and alternative supply networks therefore circumvent contemporary barriers of entry for poor southern producers. This movement of movements was highly heterogeneous in their motivations and operations (Gendron et al. 2009, pp. 64-65; Low and Davenport 2006). However, what precipitated out was a collection of governance principles under which international supply chains might return greater material benefit to southern participants. Broadly speaking, such fair trade operations involved mission-driven, Northern 'alternative trade organisations' - responsible for the purchase and import of goods - and southern producer organisations - which provided a variety of services to their members, including marketing, product development and commercialisation (LeClair 2002, p. 950). In this light, alternative trade developed supply networks isolated from conventional trade activity (Rosenthal 2011, p. 159): where the suspension of market conditions identified within a firm ${ }^{3}$ were extended down the supply chain in models of 'relational governance' usually identified within economic transactions by member of the same family or with a close identity bond (Smith 2009, p. $458 \mathrm{fn} .451$ ). At this stage, organisations did not carry any form of accreditation for their activities, but instead relied on the social orientation of their reputation to justify claims to promote greater social justice in international trade (Tran-Nguyen and Zampetti 2004, p. 391).

This situation changed in 1988 when a Dutch NGO and a Mexican coffee farmers' cooperative developed a 'third-party' governance and certification approach to provide external legitimacy to fair trade operations. The Max Havelaar mark, guaranteed that coffee had been: bought direct from cooperatives for a bottom line price of up to 10 percent higher than the world market price; refinanced by up to 60 percent; and traded within long term relationships (Brown 1993, p. 162). This development was again a considerable cross-border innovation as it facilitated the migration of fair trade goods out of alternative supply chains operated by social economy actors and into those provided by conventional profit orientated companies (Davies 2007, p. 463). By 1993 the Max Havelaar mark had a 3 percent share of the Dutch market (Brown 1993, p. 182) and this approach to fair trade encouraged the development of similar initiatives all around Europe and now across the world.

\footnotetext{
${ }^{3}$ This refers to Coase's (1937) seminal definition of the 'firm' as economic space in which market coordination is suspended.
} 
Initially, expansion of the certification approach was under a system of separate National Labelling Initiatives (NLIs), for example under the Max Havelaar name in Belgium, Switzerland and France (Nicholls and Opal 2005, p. 10), and that of the Fairtrade Foundation in the UK (Brown 1993, pp. 180-184). In 1993 however, centralisation began and in 1997 different NLIs merged to form the Fairtrade Labelling Organizations (FLO): subsequently renamed to Fairtrade International in 2011 (although still widely known by its acronym). This process involved greater centralisation and harmonisation of the different standards that existed among national certification systems, and by 2009 there were 21 FLO affiliated NLIs in Northern consumer countries promoting a unitary suite of Fairtrade International certification (FLO 2009b, p. 27). In order to be eligible for such certification, an individual product must be produced by a southern group meeting certain economic, social and environmental standards. Due to the focus on 'trade', governance also stipulates that in order for products to carry the Fairtrade Mark, the first buyer must usually: pay at least a minimum price set by FLO, or the world price where this is higher; pay an additional percentage as a Social Premium to fund development projects by the producer community; and have provided up front credit of up to $60 \%$ where requested. Buyers are also encourage to commit to long term relationships and provide indications of future demand, although these standards are not as well elaborated or enforced as core requirements.

The development of Fairtrade certification has certainly facilitated the great expansion of fair trade activity (Nicholls and Opal 2005; Tallontire 2009, p. 1005). Since the introduction of certification retail sales of fair trade goods have grow steadily year on year. Figurers from members of European Fair Trade Association indicate that from 2001 sales have increased $40 \%$ to reach €286 million in 2009 (Boonman et al. 2010, p. 23). As this data involves a variety of certified and non-certified goods, it is not possible to identify the effect of FLO endorsed products; however, at the global scale these also grown yearly, expanding 12\% from 2010 to reach $€ 4.9$ billion in 2011 (Fairtrade International 2011). Although there is no official translation of this figurers into financial benefit for the developing world (which would be significantly less given the nature of value distribution in international supply chains), it is estimated that Social Premium payments in 2011 totalled some $€ 65$ million (Fairtrade International 2012, p. 3). 
While the majority of this growth has come from the private sector due particularly to the involvement of supermarkets, increasing support from European government and even the European Union itself have certainly contributed to market expansion. In 2006 the European Parliament issued a Resolution which explicitly recognised the definition and principles of Fair Trade, agreed by major institutions within the movement (Boonman et al. 2010, p. 17). At the national level, in the UK for example, while the national labelling initiative of Fairtrade International, the Fairtrade Foundation has received grant support from the government, the state has also identified that fair trade goods can be purchased as a means to promote sustainable development through public procurement (DFID 2009).

Despite this increasing popularity and support for fair trade however, analysts identify that corporate involvement has turned FLO into a site of "negotiating, establishing, enforcing and reformulating the standards and certification' (Jaffee 2010, p. 268) in which an increasing amount of concessions have been granted to commercial players (Jaffee 2010; Renard 2005, p. 421 \& 424). This is viewed to have 'weakened' (Jaffee and Howard 2009; Renard 2010, p. 290) or even 'corrupted' (Doppler and González 2007, p. 190) the principles and practices promoted, in a way that is detrimental to the interests of southern producers (Reed 2009; Tallontire 2009). For example, corporate actors have pushed for lower minimum prices (Barrientos and Dolan 2007, p. 18; Tallontire 2009, p. 1011) and, in perhaps the most extreme case of conventionalisation, even advocated for the total removal of this component from certification (Renard 2010, p. 290). It might be argued that another area of weakening has been that while FLO mandates the payment of a social premium, there is no requirement for northern buyers to invest in southern production capacity; and where such investment has taken place, it has been aimed at the commercial needs of buyers, rather than the development interests of producers (Macdonald 2007; Tallontire 2009, p. 1009). Overall, these new interactions have led some to suggest that Fairtrade certification has facilitated a transformation of fair trade operations away from 'relational' supply chain governance models and more towards conventional structures (Reed 2009).

Also of pertinence to the current chapter, FLO has been criticised for the way it has managed access to its certification. For example, while the system was initially developed for the express purpose to support small farmers, pressure from supermarkets for large quantities of certified goods has seen extension to plantation style production; and this is argued to have been to the detriment of initial stakeholders (Renard and Perez-Grovas 2007, p. 150). On the 
other hand, although coverage has expanded well beyond the initial category of coffee - and now covers 18 separate product categories, facilitating the certification of over 300 individual raw products (Fairtrade International 2012, p. 8) - not all standards are available in all countries. For example in the case of certification for rice, only producer groups located in Thailand, Laos, India and Egypt can readily apply for certification (FLO 2009a) - and as will be discussed below, this has been to the immediate disadvantage of producers in other countries such as Malawi. Finally, while third-party certification was initially free of charge to producers, it is now necessary to pay an up-front fee of $€ 250$ and also to bear the costs of inspection and verification, levied at $€ 350$ per day (Neilson and Pritchard 2010, pp. 18471848).

In parallel to the institutionalisation of fair trade within the Fairtrade certification system, many of the original mission driven founders of the fair trade movement have continued to innovate and professionalise (Fichtl 2007, pp. 15-17); and these have been joined by others seeking to create alternative international trade circuits (Barrientos and Dolan 2007, p. 10). Although such organisations might also carry FLO certification, many of their goods remain outside of the system and instead rely on direct contact and trust to uphold their claims of fairness (Bezençon 2011, p. 61; Raynolds 2009, p. 1086). More importantly, many organisations go well beyond FLO requirements to promote the interests of southern supply partners. For example, Cafédirect and Divine Chocolate have made it an explicit aim to extend ownership to producers themselves and to invest heavily in producer capacity as a means to redress long standing power inequalities between the North and the South (Doherty and Tranchell 2005; Tallontire 2000). It is because of these practices that some refer to such organisations as having adopted the 'gold standard' of fair trade (Brown 2007, p. 272). In some cases there organisations have sought to market their products by incorporating FLO certification into their business model, although this is not always the case. What has emerged as an important issue however is that fair trade practices that go beyond FLO requirements have been at pains to communicate these additional efforts to the consumer. While some are viewed to have achieved this through diligent and innovative management of marketing strategies, there is a general concern that not all such operations have achieved this so effectively.

Having said this Fairtrade certification is not the only system of third-party legitimacy available in the market. The World Fair Trade Organisation (WFTO) also offers accreditation 
for fair trade activity that: is not able to access FLO certification due to geographical or product characteristics (Gendron et al. 2009, p. 68); or wishes to differentiate themselves from less producer focused operations (Davies 2007; Murray 2011). In either case, the key point is that the WFTO is a membership organisation which represents ' 100 per cent authentic fair trade' or dedicated socially orientated organisations (Davenport and Low 2012, p. 5). Indeed, some analysts go as far as to associated this accreditation with radical interpretations of the fair trade model (Rosenthal 2011, p. 168). This is because Fairtrade certification applies to individual products, and therefore, allows large corporate actors, often with dubious ethical records, to adopt minimal Fairtrade ranges without making fundamental changes to their wider operations. The WFTO on the other hand only accredits whole organisations whose entire operations comply with certain standards in the areas of the Ten Fair Trade Principles:

1. Creating Opportunities for Economically Disadvantaged Producers

2. Transparency and Accountability

3. Trading Practices

4. Payment of a Fair Price

5. Child Labour and Forced Labour

6. Non Discrimination, Gender Equity and Freedom of Association

7. Working Conditions

8. Capacity Building

9. Promotion of Fair Trade

10. Environment

In summary then, it has been argued that fair trade initially emerged as an innovation by civil society actors to circumvent the state based neoliberalisation of the global economy. Genuine partnerships between north-south trading partners extended the suspension of market forces within firm operations, and applied this down the supply chain in models of relational governance. However, in a further effort to escape the limited opportunities of alternative trading networks, the introduction of third-party certification is argued to have resulted in a conventionalisation of the fair trade system. In the next two sections, the chapter examines one way in which this has occurred and furthermore, how this narrowing of what fair trade activity is taken to be affects producer stakeholders in the developing world. 


\section{The Fairtrade Towns Scheme: Promoting the conventionalisation of fair trade?}

Following the success of Fairtrade International's product certification system, and indeed as one of the recent drivers of its widespread adoption (Fisher 2009, p. 995), the Fairtrade Foundation in London has built on grassroots activity to develop an important promotional tool for the movement: the Fairtrade Town (Crowther and Human 2011). This initiative can be described as a place based certification system for consumer communities. Formally launched in September 2001 the Fairtrade Town scheme offers towns, villages, cities and other geographically defined areas, the opportunity to receive Fairtrade accreditation if they are able to show evidence that:

1. The local council has passed a resolution supporting Fairtrade, and agrees to serve Fairtrade products (for example, in meetings, offices and canteens).

2. A range of Fairtrade products are readily available in the areas retail outlets (shops, supermarkets, newsagents and petrol stations) and served in local catering outlets (cafés, restaurants, pubs).

3. Local workplaces and community organisations (places of worship, schools, universities, colleges and other community organisations) support Fairtrade and use Fairtrade products whenever possible. A flagship employer is required for populations over 100,000 .

4. Media coverage and events raise awareness and understanding of Fairtrade across the community.

5. A local Fairtrade Steering Group is convened to ensure the Fairtrade Town campaign continues to develop and gain new support.

(Fairtrade Foundation 2009b)

In order to achieve Fairtrade Town accreditation, a steering group has to submit evidence that the community has met the targets and then continues to improve upon these achievements every year for the award to be renewed. In recognition that the criteria have been met, communities are presented with a certificate and permitted to erect signs to acknowledge their achievement. Such accreditation has proved very popular. By 2010, four hundred Fairtrade Towns and Cities appeared in the UK (Fairtrade Foundation 2009b) and the systems has spread to other European countries (Alexander and Nicholls 2006, p. 1245), as well as the USA, Canada, Australia and New Zealand (Crowther and Human 2011, p. 94). The concept 
of accreditation for placed based consumption communities has also spread to other institutions, and it is possible to become recognised as a Fairtrade church, university or school (Crowther and Human 2011, pp. 93-94; Fairtrade Foundation 2009a).

As can be seen above, from an examination of the Fairtrade Foundations documents, it can be assumed that the accreditation scheme specifically calls for the political support, and public and private consumption not of fair trade goods as a general category, but specifically of those carrying the Fairtrade Mark: and therefore, certified by Fairtrade International. Indeed, the 'Sample Motion' provided by the Fairtrade Foundation (No date) uses the Trademarked term 'Fairtrade' and makes further explicit references to the 'Fairtrade MARK' (original capitalisation). It is for this reason that some have concluded that these schemes "compel" community actors, including the Local Authorities "to serve Fairtrade [certified] produce during their meetings and promote Fairtrade produce in their area" (Preuss 2009, p. 217).

For this reason, Mohan (2010, p. 94) argues that despite a multitude of private ethical and pro-development certifications available in the market place, including multiple approaches to fair trade, the Fairtrade Town scheme promotes 'Fairtrade absolutism' by seeking to obtain 'a monopoly' for FLO certification; both to the exclusion of non-certified fair trade goods and differently certified goods such as that offered for example by the Rainforest Alliance (Mohan 2010, p. 98). The specific reason for this concern is that there is insufficient evidence to make a universal claim that FLO certification is necessarily the most appropriate form of private governance with which to promote the interests of southern producers (Mohan 2010, p. 98). Indeed, the process can also be argued to narrow fair trade to the consumption of Fairtrade certified goods and therefore, by implication, inadvertently promote a more reformist or conventionalised version of the fair trade concept - rather than the more radically innovative set of tools that remain within other approaches and accreditations.

Naturally however, analysis of the requirements set down by governance and certification frameworks is not sufficient evidence to infer that accredited practices are compliant - as research in a wide variety of such systems clearly demonstrates that this is perhaps very rarely the case. For this reason, empirical research was conducted in Scotland to ascertain to what extent Fairtrade Towns were generalising fair trade to focus on Fairtrade certification. The reason that Scotland was chosen was that it has taken the step of embedding a commitment to fair trade in its International Development Policy primarily by achieving 
certain levels of community accreditation from the Fairtrade Foundation (Smith 2011, pp. 101-102).

Examining the empirical reality, it can be reported that none of the Scottish councils currently registered as Fairtrade Zones have adopted the Sample Motion suggested by the Fairtrade Foundation and none of them make reference to the 'FAIRTRADE MARK' (For more detail see: Smith 2011). However, half of motions (four out of eight) which include general commitments use the trademarked term 'Fairtrade'. Out of the nine motions that make specific commitments about the practices of Local Authority procurement, four specify 'Fairtrade certification' and four commit to the purchase of 'fair trade (such as the Fairtrade Mark)'. These specific commitments to purchase or specifically prioritise Fairtrade certified goods also manifest themselves in actual purchasing behaviour. For example, a representative from one Local Authority recalled an incident where someone had telephoned to say that the company tendering to supply tea and coffee to the café/restaurant in the council headquarters was offering Rainforest Alliance certified products, and asked if this was acceptable. After consulting with the Fairtrade Steering Group it was concluded that 'because we are a Fairtrade City under the Fairtrade Foundation scheme, we should only be using tea or coffee with the FLO Mark ${ }^{4}$. This suggests that in some areas there has been a rise of what might be termed as 'Fairtrade absolutism' and an important issue is therefore how this situation might affect southern agricultural producers.

\section{Malawi and the Limitations of Fairtrade Certification}

Alongside commitments to fair trade in its International Development Policy, Scotland has also fostered specific development partnerships with various African countries: the most prominent of which has been with Malawi due to the strong historical precedence of such interactions $^{5}$. Indeed, in 2005, the then First Minister of Scotland, Jack McConnell, and President wa Mutharika of Malawi, signed the Scotland-Malawi Co-operation Agreement. Here it was identified that the two countries would cooperate in various areas including civic

\footnotetext{
${ }^{4}$ Interview with Council Representative 05/01/2010.

${ }^{5}$ This signalling out of Malawi is grounded in the historical precedent of Scottish involvement with the area as early as 1859 (Scottish Government 2007), when the celebrated explorer, Dr Livingstone, is believed to have contributed beneficially to the area.
} 
governance and society, health, education, as well as 'sustainable economic development' (Scottish Government 2005, p. 1).

Despite this support, the development challenges in Malawi are significant. Situated in southeastern Africa, the country is among the poorest and least economically developed in the world (World Bank 2009). Despite the absence of current or recent violent conflict (OECD 2007, p. 331), Malawi is ranked 171 out of 187 in the United Nations Human Development Index; 74 percent of the population earn below the poverty line; and life expectancy is a meagre 54 years (United Nations 2011). Furthermore, history, geography and politics combine to make altering this situation strikingly difficult (Ellis et al. 2003). The small country is landlocked, densely populated with poor infrastructure, and is heavily dependent on agriculture for 35 percent of GDP and over 53 percent of export earnings (Booth et al. 2007, p. 6; Harrigan 2003, p. 847; Tsutomu 2009, p. 358). Specifically, the sale of tobacco provides the biggest single contribution, generating 70 percent of foreign exchange and 30 percent of GDP (Malawian Government 2009; Orr 2000, p. 348). As such, Malawi is highly vulnerable to external price shocks and declining terms of trade. As the country imports all its fuel products, inflation is strongly linked to both international petroleum and diesel prices (OECD 2008, p. 405). The national currency of Malawi, the Kwacha has a long history of value adjustments (Kherallah et al. 2001, p. 26) and in 2005, the government pegged the exchange rate to the US Dollar. While depressing the cost of imports, reliance on an overvalued exchange rate raised the cost of selling goods on international markets; reportedly reducing their volume; contributed to a ongoing lack of foreign exchange; and facilitated a significant balance of payments crisis (Chiyembekeza 2010; Govenor of the Reserve Bank of Malawi quoted in Malawi News 2009, p. 8) ${ }^{6}$.

It was in this context that the National Smallholder Farmers Association (NASFAM) first became involved in fair trade as they saw the innovative approach to export trade as a way to both promote alternative livelihoods and generate much needed foreign exchange. In 2003 the organisation began to obtain certification from Fairtrade International for the Mchinji Area Smallholder Farmers Association (MASFA) as a groundnut producing cooperative, and

\footnotetext{
${ }^{6}$ The rate of this depression has now become evident after the liberalisation of the MK in May 2012 when markets have settled around a rate of MK250/USD, although reportedly still below the black-market level of closer to MW275/USD (Reuters 2012).
} 
itself as a registered Fairtrade exporter. With certifications being ratified in 2004, MASFA sent its first shipment of 64 metric tons of groundnuts to the UK in 2005; and subsequently 36 metric tons in 2006, 450 metric tons in 2007 and was expected to have sent around 1,170 metric tons in 2008.

As is established in the existing literature on fair trade, this is of significant importance as the volume of goods sold under certified conditions can dramatically affect of level of benefit derived from investment in fair trade operations. Although volumes were initially low, from 2007 to 2011 groundnut exports to the UK generated an income of $\$ 527,000$ and Fairtrade premiums to the value of $\$ 58,000$ (Analysis of NASFAM records). More specifically, MASFA have used the Social Premium to construct a Guardian shelter ${ }^{7}$ at Mchinjii hospital and invested in processing and export capacity: such as a warehouse for safer storage of their groundnut crops.

On the basis of this experience, NASFAM has also sought FLO certification for other Associations - particular one at Mzimba, which also produces groundnuts. However, at the time of fieldwork it was noted that while the group was in theory eligible for certification, the funds required to meet necessary fees were simply not available. NASFAM's Commercial Manager explained that 'we have an association, a very productive association-we just don't have on any of the budgets around $€ 3,000$ to certify them. We have already paid a bit for the audit, if we don't certify this year we have to start from scratch'. This view is supported by other interviews in Malawi ${ }^{8}$ and also wider analysis that since the shift to charging producer organisations for their certification, some have not been able to afford the investment. The General Manager of NASFAM Commercial makes the analogy that the Fairtrade certification system

'....acts as if you are telling somebody without shoes, ok, I can get you shoes later on, but can you give me your slip-ons. So the guy has to look around for the money to buy the slip-ons, so when they now donate the slip-ons, they are now promised a pair of shoes"9.

\footnotetext{
${ }^{7}$ The Guardian shelter provides shelter for relatives and patients visiting and caring for friends and family staying at the hospital.

${ }^{8}$ Interview with Anonymous Stakeholder 16/11/2009.

${ }^{9}$ Interview with Joshua Varela 5/11/2009.
} 
Another group that NASFAM would like to embed in fair trade supply networks is the Kaporo Small Farmers' Association (KSFA) located in the north of the country in the town of Karonga. This community of farmers is of particular interest to NASFAM as it produces Kilombero rice. Exporting this crop is especially attractive is it has high value potential and also offers a non-traditional export for the organisation and country as a whole. Unfortunately, while Fairtrade International offers certification for the production and export of rice, it is understood by stakeholders to be difficult and currently impossible to obtain in Malawi ${ }^{10}$. This is because only producer groups located in Thailand, Laos, India and Egypt can readily apply for certification (FLO 2009a) and only where they are growing certain varieties under certain production methods. As a result, before KSFA or any organisation in Malawi could have their rice certified by FLO, it would be necessary to arrange for the Product Standard to be extended to the country: the primary obstacle of which is setting the minimum price level that would be applied.

This issue of exclusion and extension is something that has been addressed in Fairtrade International's most recent Strategic Review. Indeed, the current view is that there 'shouldn't be a barrier now' as even where national price structures exist for certain commodities, there is 'now a mechanism for setting that much more quickly' (Interview with senior FLO representative). Unfortunately, when FLO representatives were approached by stakeholders in the Kilombero rice supply chain, no mention of this possibility was made. Indeed, the request was met with the response that nothing could be done until the next price review meeting of FLO's central board, and no preparatory measures were suggested ${ }^{11}$. Although NASFAM have subsequently been offered the option to develop the standard themselves by agreeing a price with a buyer in the market (one of the recognised procedures for expanding the geographical coverage of FLO certification), they are resisting this option given the expected cost and uncertain returns in the initial trading period ${ }^{12}$.

In summary, the problems associated with any tendencies towards 'Fairtrade absolutism' are clearly manifest in this example of a producer group frustrated by the difficulties in accessing Fairtrade certification. In the case where only Fairtrade International certification is

\footnotetext{
${ }^{10}$ Interview with Andrew Parker 23/11/2009.

${ }^{11}$ Personal communication with an anonymous informant.

${ }^{12}$ Personal communications with anonymous informants.
} 
recognised as a valid fair trade methodology, southern producers unable to obtain this will inevitably find themselves isolated from fair trade markets: therefore reducing the innovative capacity of fair trade activity. However, where interpretations of what constitutes fair trade are wider, this approach to international trade might resist these challenges. In this light, the final section links together the two case studies above, with an example of how continued cross-border innovation in what constitutes fair trade might well offer a method through which to circumvent these problematic issues.

\section{Cross Border Innovation: The fair trade of Kilombero rice between Malawi and Scotland}

Returning back to Scotland, although some Fairtrade Towns phrase their commitments to specifically support the consumption of Fairtrade certified goods, there are also others which word these in a more general way. For example, five of the motions avoid specific references to 'Fairtrade', and instead phrase their commitments in terms of the more general category of 'fair trade' or 'fairly traded'. While in some cases the choice between policy wordings can be more down to stylistic choice or automatic spell-checkers ${ }^{13}$, in Edinburgh choices were made very deliberately. When asked about the reasons for wording policy in terms of 'fair trade', a representative of Edinburgh City Council replied that:

'It's a very fundamental question... we went down the sort of exemplar policy statement that the Fairtrade Foundation had advised us along the lines of...[However] we were advised by our fair trade, well, activists here in Edinburgh, people who had been working in the fair trade area for a long, long time, [who] were saying that two words when you are talking about fair trade in general, or as in I'm going to buy fair trade chocolate, but if you are talking about anything that the Foundation talk of, like Fairtrade Fortnight, Fairtrade Cities, Fairtrade Zones, Fairtrade schools, its two words - one word, I mean one word'.

This innovation of opening up the agenda of Fairtrade Towns beyond the implied restriction to FLO certified goods is also found in East Dunbartonshire. Here the council has passed a resolution to procure 'fairly traded' goods and has also purchased a wide range of variously

\footnotetext{
${ }^{13}$ Interview with Sylvia Grey 16/06/2009.
} 
certified products for use in a range of public institutions. Of particular interest in the context of studies concern with cross-border innovation however, has been their purchase of 'fairly traded' Kilombero rice: the same rice produced by KSFA in Malawi and which is imported into Scotland by a dedicated fair trade organisation, Just Trading Scotland (JTS), despite its lack of FLO accreditation.

In brief summary, the Local Authority took on the rice for use in school during Fairtrade Fortnight: an annual promotion drive, run by the Fairtrade Foundation as a means to boost interest in FLO certified products. In the previous year, the Local Authority had used FLO certified pasta in schools, although the Sustainable Development Officer decided that simply serving pasta left little opportunity to highlight the difference between fair trade and 'non-fair trade' ingredients to the children ${ }^{14}$. For this reason, a partnership between JTS and the council produced an education pack to accompany the serving of rice which explained the wider context and the issue of global trade justice that were involved. In explaining how this innovation occurred a representative of the council explained that 'this is where the [Fairtrade Town steering] group pays dividends...It took the group to deliver this...[as] it was the educational spokesman that would push the educational side, the citizenship, but as a catering supplier it fitted my needs as well ${ }^{15}$. Furthermore, while the rice was initially procured for use at a specific time of year during Fairtrade Fortnight, it has subsequently been used in Local Authority catering across a variety of institutions and further orders have been placed with the supplier.

While those responsible for the purchase of the rice were aware that the produce was not Fairtrade certified, knowing the origins and background of the rice, they were satisfied that the product fitted the broader principles of the fair trade agenda as they understood them. This is because the rice comes from one of the poorest countries in the world, where the economic situation strongly suggests that the promotion of non-traditional exports is highly important for development. In addition, the fair trade nature of the supply chain stems from the fact that as a democratically organised membership organisation, NASFAM pays prices to farmers based on a calculation of the sustainable cost of production - as opposed to exploiting market failures to drive down the price of agricultural produce as is the practices

\footnotetext{
${ }^{14}$ Interview with John Riches 19/03/2009. Interview with Grace Irvine 16/06/2009.

${ }^{15}$ Interview with Grace Irvine 16/06/2009.
} 
of other domestic buyers in the country (Chirwa et al. 2002). In order to extend the social embedding of transactions to the international context, JTS have worked with NASAFM to provide a price that also incorporates domestic transaction costs (processing and transport) based on transparent discussions. Further to this, in the spirit of more radical and innovative fair trade operation, JTS have facilitated the funding of infrastructural improvements to process the rice in the community where it is produced. The farmers' Association can now clean, process and bag its own produce and thus the investment facilitates a well recognised and fundamental process in economic development: the maximum capture or addition of value, both in the community and country of origin. Overall, the supply chain can be consider to be coordinated by the type of 'relational' governance that initially dominated the fair trade movement and is characteristic of more radical, contemporary, fair trade operations (see Reed 2009).

Given the nature of their interactions and operations, JTS and Imani Development (the importer's development partner in Malawi), have played an important role in highlighting the opportunity to accredit the Kaporo producer Association through the WFTO $^{16}$. While there remains some concern that such accreditation will not be as well recognised as certification provided by Fairtrade International, the costs involved are minimal and the system is much more accessible to the organisation (see above). In summary, the example of Kilombero rice is a testimony to the potential of continuing cross-border innovation to generate market access for poor small farmers in the developing world. While third-party certification has a great role to play in breaking the need for fair trade to be embedded in trust and knowledge flows, where this proves inappropriate or impossible, it is concluded that more radical uses of social capital can bring great opportunities.

\section{Conclusion}

During the last 20 years, the cross-border innovation of fair trade governance, designed to structure South-North supply chains in ways more beneficial for southern stakeholders, has gained significant attention. However, it has been argued above that what started as

\footnotetext{
${ }^{16}$ The fieldwork on which this chapter is based also identified very similar processes of negotiation and contestation concerned with the interpretation of what it means 'to do fair trade' in Malawi.
} 
international cooperation between isolated mission driven actors has been largely co-opted and by corporate and profit making interests. As a result innovation has been reduced as the use of interventionist tools has been weakened: for example, where the structural integration of producer support has been reduced to an additional Social Premium payment and profit orientated actors have even advocated for the withdrawal of the minimum price system.

More specifically, it has been noted that despite the benefits of widening fair trade participation, the rise of Fairtrade International has had the adverse effect of pushing other fair trade approaches to the margins of the movement. This has been of particular concern as it is these alternative practices which are considered to contain the most promising potential for innovation within international supply chain governance. Investigating the effects of the Fairtrade Towns scheme administered by the UK's Fairtrade Foundation, it was found that in Scotland there is evidence for the rise of 'Fairtrade absolutism'. The reason for this is that the requirements to become a Fairtrade Town are often interpreted literally, with communities and local authorities exclusively building their actions around the consumption of Fairtrade certified goods. Furthermore, empirical detail was added to the problems of such a development through discussion of NASAFM as a producer case study. While this organisation has had some success in exporting Fairtrade groundnuts, the cost of further certification has proved a great limitation; and which producer representatives themselves see as a great irony of the system. Although the organisation has other products produced under fair trade conditions, they have not been able to obtain certification as despite being available in other countries, this is not currently the case for Malawi. Although mechanisms do exist for the geographical extension of this opportunity, FLO's administration has proved slow in facilitating the realisation of this opportunity; although, testimony suggests this was more of an issue with particular personnel than the system as a whole. This being said, NASFAM remain hesitant to pursue Fairtrade certification due to the costs involved.

In this context the final section of the chapter has linked together research on Fairtrade Towns and the producer experience in Malawi. Specifically, analysis has taken a supply chain approach to report on an alternative 'community of interpretation' around the concept of fair trade. Here it is illustrated that where consumers, individual and/or institutional, have a more open minded and wider understanding of what legitimately counts as fair trade operation, continued innovation can prevent the exclusion of legitimate stakeholders from fair trade relationships. Indeed, contrary to other communities, East Dunbartonshire has 
conspicuously avoided specific references to Fairtrade certification in its policy aims, instead considering the more general terms of 'fair trade' and 'fairly traded' activities: an interpretation which has also filtered through to practical action as the community has promoted the consumption of a variety of certified goods. Beyond this, the local authority have been keen to replace simple consumption with a more holistic education package for delivery in schools, and this has led to the ongoing procurement of fairly traded rice. While the scale of this project might be viewed as insignificant, there is great importance in this example as it highlights the opportunities for civil society and state actors working within the fair trade movement to resist and negotiate the meaning of the FLO centric Fairtrade Towns scheme. Furthermore, the hugely important role of mission driven fair trade organisations is highlighted, as it is these actors that are arguably the epicentre of innovation in fair trade praxis: influencing as they do the interpretations and actions of both producer and consumer communities.

What is important moving forward is that research extends collective understanding of how fair trade is being operationalised in a variety of contexts and moreover, critically investigates the options for further increasing levels of innovation in economic governance. Indeed, understanding of these dynamics is of critical importance. The growing popularity of promoting 'relational' relationship supply chain governance in a variety of sectors and contexts is increasingly evident: particularly in cases where state authority is drawing on these principles as matter of government policy and action (for example, see the legal definition of 'fair trade' in France and the developments of the solidarity economy in Brazil). While understanding the empirical benefits of these initiatives will be of huge importance, the role of conceptual development and interpretation in contributing to praxis will be key in understanding differentiated outcomes. Only through an adequate consideration of such linguistically embedded innovations will it be possible to evaluate the contribution of alternative economies to global sustainability and development. 


\section{Bibliography}

Alexander, A. and Nicholls, A. 2006. Rediscovering consumer-producer involvement: A network perspective on fair trade marketing. European Journal of Marketing (40), pp. 11-12.

Barrientos, S. and Dolan, C. 2007. Transformation of Global Food: Opportunities and Challenges for Fair Trade and Ethical Trade. In: Barrientos, S. and Dolan, C. eds. Ethical Sourcing in the Global Food System. London: Earthscan.

Bezençon, V. 2011. Producers and the Fair Trade Distribution Systems: What are the benefits and problems? Sustainable Development 19(1), pp. 60-70. http://dx.doi.org/10.1002/sd.420.

Boonman, M., Huisman, W., Sarrucco-Fedorovtsjev, E. and Sarrucco, T. 2010. Fair Trade Facts and Figures: A Success story for Producers and Consumers. Culemborg, The Netherlands: Dutch Association of Worldshops (DA WS). http://www.european-fair-tradeassociation.org/efta/Doc/FT-E-2010.pdf.

Booth, D., Cammack, D., Harrigan, J., Kanyongolo, E., Mataure, M. and Ngwira, N. 2007. Drivers of Change and Development in Malawi. Working Paper. 261. London: Overseas Develompent Institute. http://www.odi.org.uk/resources/download/1318.pdf. Accessed on: $17 / 02 / 10$.

Brown, M. B. 1993. Fair Trade: Reform and realities in the international trading system. London: Zed Books.

Brown, M. B. 2007. "Fair Trade" with Africa. Review of African Political Economy 34(112), pp. 267-277. http://www.informaworld.com/10.1080/03056240701449653.

Chiyembekeza, C. 2010. Malawi Trade Gap Worsens. The Nation.

http://www.mwnation.com/index.php?option=com_content\&view=article\&id=9562:malawitrade-gap-widens\&catid=13:business-review\&Itemid=14. Accessed on: 10/01/2011.

Coase, R. H. 1937. The Nature of the Firm. Economica 4(16), pp. 386-405. http://www.jstor.org/stable/2626876

Crowther, B. and Human, J. 2011. The Fairtrade Revolution in Progress: Campaigning for justice. In: Bowes, J. ed. The Fair Trade Revolution. London: Pluto Press, pp. 89-106.

Davenport, E. and Low, W. 2012. The World Fair Trade Organization: From trust to compliance. In: Reed, D., Utting, P. and Mukherjee-Reed, A. eds. Business Regulation, NonState Actors and Development: Whose Standards? Whose Development? London: Routledge.

Davies, I. A. 2007. The Eras and Participants of Fair Trade: An industry structure/stakeholder perspective on the growth of the fair trade industry. Corporate Governance Journal 7(4), pp. 455-470.

DFID (Departement for International Development) 2009. Eliminating World Poverty: Building our common future. White Paper on International Development. London: 
Department for International Development.

http://webarchive.nationalarchives.gov.uk/+/http://www.dfid.gov.uk/documents/whitepaper/b uilding-our-common-future-print.pdf. Accessed on: 01/05/2011.

Doherty, B. and Tranchell, S. 2005. New Thinking in International Trade? A case study of The Day Chocolate Company. Sustainable Development 13(3), pp. 166-176.

Doppler, F. and González, A. A. 2007. El Comercio Justo: Entre la institucionalización y la confianza. Problemas del Desarrollo 38(149), pp. 181-202.

Ellis, F., Kutengule, M. and Nyasulu, A. 2003. Livelihoods and Rural Poverty Reduction in Malawi. World Development 31(9), pp. 1495-1510.

http://www.sciencedirect.com/science/article/B6VC6-49202J6-

$\underline{4 / 2 / 21 \mathrm{f} 665 \mathrm{~d} 81 \mathrm{f} 650631 \mathrm{c} 4 \mathrm{aaebd} 209 \mathrm{~b} 132 \mathrm{~b} 0}$

Fairtrade Foundation 2009a. About Fairtrade Universities and Colleges [Online].

http://www.fairtrade.org.uk/get_involved/campaigns/fairtrade_universities/about_fairtrade_u niversities.aspx. Accessed: 01/05/2011.

Fairtrade Foundation 2009b. Fairtrade Towns: The five goals [Online]. http://www.fairtrade.org.uk/get_involved/campaigns/fairtrade_towns/the_5_goals.aspx. Accessed: 01/05/2011.

Fairtrade Foundation No date. Fair Trade Towns Council Motion [Online]. http://www.fairtrade.org.uk/includes/documents/cm_docs/2008/t/towns_council_motion.pdf Accessed: 14/06/2009.

Fairtrade International 2011. Fairtrade releases financial and sales figures [Online]. http://www.fairtrade.net/single_view1.0.html?\&tx_ttnews[tt_news]=257\&cHash=e8a1c240f2 0d96aaab4ec0aaad9889c4. Accessed: 25/01/2012.

Fairtrade International 2012. For Producers, With Producers: Annual Report 2011-12. Bonn, Germany: Fairtrade International.

http://www.fairtrade.net/fileadmin/user_upload/content/2009/resources/2011$\underline{12 \_ \text {AnnualReport_web_version_small_FairtradeInternational.pdf. }}$

Fichtl, E. 2007. The Fair Trade Movement in Histrical Perspective: Explaining the "in and against the market" predicament. New School.

http://www.ericfichtl.org/index.php/texts/pages/fair_trade_movement.

FINE 2001. Fair Trade Definition and Principles. Brussels: Fair Trade Advocacy Office. http://www.fair-trade-hub.com/support-files/fair-trade-definition.pdf. Accessed on: 01/05/2011.

Fisher, E. 2009. Policy Arena Introduction: The policy trajectory of fair trade. Journal of International Development 21(7), pp. 985-1003. http://dx.doi.org/10.1002/jid.1633.

FLO (Fairtrade Labelling Organisations International) 2009a. Fairtrade Minimum Price and Fairtrade Premium Table. 
FLO (Fairtrade Labelling Organisations International) 2009b. Fairtrade: Leading the Way. Annual Report. Bon: Fairtrade Labelling Organisations International.

http://www.fairtrade.net/fileadmin/user_upload/content/2009/resources/FLO_ANNUAL_RE PORT_08-09.pdf. Accessed on: 15/05/2010.

Fridell, G. 2007. Fair Trade Coffee: The prospects and pitfalls of market driven justice. London: University of Toronto.

Gendron, C., Bisaillon, V. and Rance, A. 2009. The Institutionalization of Fair Trade: More than just a degraded form of social action. Journal of Business Ethics 86(S1), pp. 63-79. http://dx.doi.org/10.1007/s10551-008-9758-4.

Gereffi, G., Humphrey, J. and Sturgeon, T. 2005. The Governance of Global Value Chains. Review of International Political Economy 12(1), pp. 78-104.

Harrigan, J. 2003. U-Turns and Full Circles: Two decades of agricultural reform in Malawi 1981-2000. World Development 31(5), pp. 847-863. http://www.sciencedirect.com/science/article/B6VC6-4893VK52/2/61045965df18cd9fcef4eda18662b22b

Herman, A. 2010. Connecting the complex lived worlds of fairtrade. Journal of Environmental Policy and Planning 12(4), pp. 405-422.

http://search.proquest.com/docview/847274963?accountid=9883

http://elibrary.cf.ac.uk/sfx?genre=article\&amp;sid=ProQ:\&amp;atitle=Connecting+the+comp lex+lived+worlds+of+fairtrade\&amp;title=Journal+of+environmental+policy+and+planning \&amp;issn=1523-908X\&amp; date $=2010-12$ -

$\underline{01 \& a m p ; \text { volume }=12 \& a m p ; \text { issue }=4 \& a m p ; \text { spage }=405 \& a m p ; a u=H e r m a n \% 2 C+\text { Agatha } .}$

Jaffee, D. 2010. Fair Trade Standards, Corporate Participation, and Social Movement Responses in the United States. Journal of Business Ethics 92(0), pp. 267-285. http://dx.doi.org/10.1007/s10551-010-0583-1.

Jaffee, D. and Howard, P. 2009. Corporate Cooptation of Organic and Fair Trade Standards. Agriculture and Human Values, pp. 1-13. http://dx.doi.org/10.1007/s10460-009-9231-8.

Kherallah, M., Minot, N., Kachule, R., Soule, B. G. and Berry, P. 2001. Impact of Agricultural Market Reforms on Samllholder Farmers in Benin and Malawi. International Food Policy Research Institute, the University of Hohenheim, and Collaborating African Institutions. http://www.ifpri.org/publication/impact-agricultural-market-reformssmallholder-farmers-benin-and-malawi-0.

LeClair, M. S. 2002. Fighting the Tide: Alternative trade organizations in the era of global free trade. World Development 30(6), pp. 949-958. http://www.sciencedirect.com/science/article/B6VC6-45C00DJ4/2/acd54442538d96bab2400bae7cd7590e

Littrell, M. A. and Dickson, M. A. 1999. Social Responsibility in the Market Place. London: Sage. 
Low, W. and Davenport, E. 2006. Mainstreaming Fair Trade: Adoption, assimilation, appropriation. Journal of Strategic Marketing 14(4), pp. 315 - 327.

Macdonald, K. 2007. Globalising Justice Within Coffee Supply Chains? Fair Trade, Starbucks and the transformation of supply chain governance. Third World Quarterly 28(4), pp. 793-812. http://www.informaworld.com/10.1080/01436590701336663

Malawi News 2009. Forex Woes Hit Crisis Point Malawi News. 47 No. 2899.

Malawian Government 2009. Malawi President Threaten to Arrest Expelled Tobacco Buyers [Online]. http://www.malawi.gov.mw/story.php?id=326. Accessed: 24/08/2010.

Mohan, S. 2010. Fair Trade Without the Froth. London: Institute of Economic Affairs.

Murray, R. 2011. Raising the Bar or Directing the Flood. In: Bowes, J. ed. The Fair Trade Revolution. London: Pluto Press, pp. 205-206.

Neilson, J. and Pritchard, B. 2010. Fairness and Ethicality in their Place: The regional dynamics of fair trade and ethical sourcing agendas in the plantation districts of South India. Environment and Planning A 42(8), pp. 1833-1851.

http://www.envplan.com/abstract.cgi?id=a4260.

Nicholls, A. and Opal, C. 2005. Fair Trade: Market-driven ethical consumption. London: Sage.

OECD (Organisation for Economic Cooperation and Development) 2007. Malawi. African Economic Outlook. Paris: OECD. http://www.oecd.org/dataoecd/26/36/38562851.pdf. Accessed on: 18/02/10.

OECD (Organisation for Economic Cooperation and Development) 2008. Malawi. African Economic Outlook. Paris: OECD.

Orr, A. 2000. 'Green Gold'?: Burley tobacco, smallholder agriculture and poverty alleviation in Malawi. World Development 28(2), pp. 347-363.

Preuss, L. 2009. Addressing Sustainable Development Through Public Procurement: The case of local government. Supply Chain Management: An international journal 14(3), pp. 213-223.

Raynolds, L. 2009. Mainstreaming Fair Trade Coffee: From partnership to traceability. World Development 37(6), pp. 1083-1093.

http://www.sciencedirect.com/science/article/pii/S0305750X08002994.

Reed, D. 2009. What do Corporations Have to do with Fair Trade? Positive and normative analysis from a value chain perspective. Journal of Business Ethics 86(0), pp. 3-26.

http://dx.doi.org/10.1007/s10551-008-9757-5

Renard, M.-C. 2005. Quality Certification, Regulation and Power in Fair Trade. Journal of Rural Studies 21(4), pp. 419-431. http://www.sciencedirect.com/science/article/B6VD94HDX6RP-1/2/797d3206574abd8d2055d5e4f8bd044c 
Renard, M.-C. 2010. In the Name of Conservation: CAFE Practices and fair trade in Mexico. Journal of Business Ethics 92(0), pp. 287-299. http://dx.doi.org/10.1007/s10551-010-0584-0.

Renard, M.-C. and Perez-Grovas, V. 2007. Fair Trade Coffee in Mexico: At the center of the debates. In: Reynolds, L.T., Murray, D. and Wilkinson, J. eds. Fair Trade: The challenges of transforming globalisation. London: Routledge, pp. 138-156.

Reuters 2012. Malawi ends currency peg to US dollar [Online]. http://www.globaltimes.cn/NEWS/tabid/99/ID/708270/Malawi-ends-currency-peg-to-USdollar.aspx. Accessed: 17/05/2012.

Rosenthal, J. 2011. The Greatest Challenge. In: Bowes, J. ed. The Fair Trade Revolution. London: Pluto Press, pp. 157-172.

Samuel, A. and Emanuel, L. 2012. Fairtrade Towns:Place(ing) Responsibility. Spaces and Flows: An International Journal of Urban and ExtraUrban Studies 2(2), pp. 191-202.

Scottish Government 2005. Scotland Malawi Co-operation Agreement. Scottish Government.

Scottish Government 2007. Dr David Livingstone [Online].

http://www.scotland.gov.uk/Topics/Government/International-

Relations/internationaldevelopment/malawi/davidlivingstone. Accessed: 12/03/2010.

Smith, A. M. 2009. Fair Trade, Diversification and Structural Change: Towards a broader theoretical framework of analysis. Oxford Development Studies 37(4), pp. 457-478 http://www.informaworld.com/smpp/content $\sim$ content $=\mathrm{a} 916449660 \sim \mathrm{db}=$ all $\sim$ jumptype $=\mathrm{rss}$ or http://orca.cf.ac.uk/6918/1/Fair_Trade_Diversification_and_Structural_Change_final_draft_copy_copy_for_ORCA.pdf.

Smith, A. M. 2011. Fair Trade, Public Procurement and Sustainable Development: A case study of Malawian rice in Scotland. PhD Thesis, School of Planning and Geography \& ESRC centre for Business Relationships, Sustainability and Society, Cardiff University. http://orca.cf.ac.uk/10706/.

Tallontire, A. 2000. Partnerships in Fair Trade: Reflections from a case study of Cafédirect. Development in Practice 10(2), pp. 166-177.

http://www.ingentaconnect.com/content/routledg/cdip/2000/00000010/00000002/art00003

Tallontire, A. 2009. Top Heavy? Governance issues and policy decisions for the fair trade movement. Journal of International Development 21(7), pp. 1004-1014.

http://dx.doi.org/10.1002/jid.1636.

Tran-Nguyen, A.-N. and Zampetti, A. B. 2004. Trade and Gender, Opportunities and Challenges for Developing Countries. UNCTAD/EDM/2004/2. United Nations.

Tsutomu, T. 2009. Disparities and Diversities Among Female-Headed Households in Rural Malawi after 20 Years of Economic Liberalization. Singapore Journal of Tropical Geography 30(3), pp. 358-372. http://dx.doi.org/10.1111/j.1467-9493.2009.00379.x 
United Nations 2011. Human development: statistical annex.

http://hdr.undp.org/en/media/HDR_2011_EN_Tables.pdf.

World Bank 2009. World Development Indicators 2009. Washington D.C.: World Bank. 